\title{
Introduction to Symposium on Right-to-Work Legislation in the United States
}

\author{
Victor G. Devinatz
}

Published online: 21 September 2011

(C) Springer Science+Business Media, LLC 2011

In this issue's Perspectives section, I am most pleased to present this symposium on rightto-work (RTW) legislation in the United States. Since states first implemented RTW laws more than 60 years ago, both union supporters and opponents of labor organizations have vigorously debated the merits of, and the effects that, these laws have had on the U.S. trade union movement and the nation's workers as a whole. With lawmakers in a number of states introducing RTW bills in 2011, this issue remains a lively topic among employee relations scholars and makes the publication of this symposium quite timely.

This symposium consists of three essays. In the first article entitled "The Continuing Controversy over Right-to-Work Laws in the Early Twenty-First Century," I provide basic information and research concerning RTW legislation to help frame the discussion for the two remaining contributions, both written by experts on RTW laws who express dissenting views in their essays. In the second piece entitled, "How Right to Work Is Destroying the American Labor Movement: From the Ku Klux Klan to the Tea Party, Dr. Raymond Hogler, Professor of Management at Colorado State University and former Distinguished Chair in Labor Law at the University of Tuscia (Viterbo, Italy), argues that RTW legislation fails to stimulate economic development in states where such laws are present while, in addition, being hostile to the economic and social interests of U.S. workers. In the third essay entitled, "The Economic Effects of Right to Work Laws," Dr. Richard Vedder, the Edwin and Ruth Kennedy Distinguished Professor of Economics at Ohio University, contends that such legislation is becoming increasingly important given the significant movement of labor and capital from nonRTW to RTW states over the last decade. Vedder maintains that, while controlling for an array of factors, such laws are positively correlated with increasing income per capita and an improved quality of life for residents of RTW states.

Other symposiums on important employment relations topics are planned for future issues of the Employee Responsibilities and Rights Journal. If any of the journal's readers have suggestions for symposiums on specific topics, please do not hesitate to contact me. I hope that you enjoy this symposium and find it most illuminating.

V. G. Devinatz $(\bowtie)$

Department of Management \& Quantitative Methods, Illinois State University,

Normal, IL 61790-5580, USA

e-mail:vgdevin@ilstu.edu 